\title{
Designing Safe Street for Women
}

\author{
Suhaila Abdul Rashid, Mohammad Hussaini Wahab, Wan Nurul Mardiah Wan Mohd Rani
}

\begin{abstract}
Urbanisation is increasing rapidly and street design are affected due to current needs which are depending on motorised vehicles. Street become a thouroughfare and pedestrian needs are neglected. The charm of old street where priority were given to pedestrian and cyclist has lost. Pedestrian needs are constantly affected by the changing of built environment especially for women. The way women perceive a safe environment is rather different compared to men even though men do face risk in the environment. In order to create a safe street, the elements are not merely on the street but physical and social elements around it. The design of built environment does affect the way people perceive and behave. The aim of this research is to explore women's perception of safety in the streets of Kuala Lumpur particularly at Jalan Tunku Abdul Rahman. The study adopted a mixed-method approach of qualitative and quantitative in order to understand the safety perception among women that will later establish the relationship between built environment and human psychology. Respondents were selected randomly around Jalan Tunku Abdul Rahman. Questionnaire survey forms were distributed and structured observation was conducted at interval period at these streets to examined and assess women's behavior. Finding shows that fear does affect women's perception and physical design of the streets are important in affecting their behavior.
\end{abstract}

Index Terms: Public Realm, Public Space, Street Design, Urban Design, Sustainable Development, Women's Perception.

\section{INTRODUCTION}

The changes in economic, health, education and technology has affected the demographic trend especially for women [1]. Women's role in many sectors [2] are increasing due to accessibility to the above facilities. With this role play, women are more exposed to many issues in public spaces than before especially on the street where crime mostly happen. The push factor forces women to use public space i.e. streets as a way to commute daily for work.

According to previous research, crime are increasing in both developed and developing countries. Crime happen when there is an opportunity [3] for culprit and one of the factor is the built environment itself. Bukit Aman Crime Prevention and Community Safety Department [4] highlighted that there are 19,299 street crime nationwide where 13,671 cases involving gang robberies without firearms and 3249 cases involving weapons. Due to this, Royal Malaysia Police have provided frequent vehicle patrol in small lane along major city road.

Revised Manuscript Received on June 22, 2019.

Suhaila Abdul Rashid, Universiti Teknologi Malaysia

Mohammad Hussaini Wahab, Universiti Teknologi Malaysia

Wan Nurul Mardiah Wan Mohd Rani, Universiti Teknologi Malaysia
They are also working together with Kuala Lumpur City Hall on a 'safer city' programme with initiative like providing more lighting on back alleys and secluded area as well as making pedestrian walkways inaccessible to motorcycle. A good, well design and maintain built environment is crucial especially in rapid urbanization process. The urgency and needs of modern life caused an urbanized environment that gives priority to vehicular. Pedestrian are neglected during the design process where street become a thoroughfare instead of public realm.

Previous research and safety survey found that man feel safe walking on the street compared to women. Women's use of the public realm is characterised by higher use of shopping centres, parks, pathways, residential areas and public transport settings. Due to this, UN Women, UNICEF and UN Habitat [5] launched 'Safe and Sustainable Cities for All' joint programme involving many countries which addressed the need for a safer and sustainable cities for general public and for women specifically. UN Women Safe Cities Global Initiative has also taken steps to overcome safety issue especially for women in public spaces UN Women [6] identified that there is a need in gender approach in urban design to ensure the needs of women and men are taken into accounts throughout all municipal department's planning This research is investigating factors that are affecting safety perception among women on the street.

\section{BACKGROUND}

There are many challenges in urbanization where it creates many opportunities for development as well as damaging the existing spatial quality through urban sprawl [7], urban crime and other issues related to rapid urbanization. Under the Goal 11: (Sustainable Cities and Communities) [7], issues of safety are addressed as part of the goal that need to be improve. According to Mehta [8] street has been recognised as public space by modern urban societies rather than the town square or the piazza. According to Jacobs [9] the best streets are comfortable to walk along with leisure and safety. Street also shapes the form and comfort of urban community [9] and it is a political space. Street as social space are spaces for expression, for public to use not as thoroughfare but as public realm where they can use it safely at anytime. UN Habitat [10] has identified the contribution of street as public spaces on the prosperity of cities, which finds a correlation between a well-designed street grids and prosperity [10].Street in modern setting is viewed as a contributor to public life. Vibrant street life relies on certain physical qualities of the public realm to host and strengthen activities and behaviours. Streets and public space are both a setting and an agent for social interactions that make a place interesting and engaging.

Published By: 
Current street design should incorporate sustainability of the spatial design and the street specifically as this is the back bone of a city where people us it on daily basis. The effort of creating a safe environment should involves many parties from Local Government, designers, developer and even the public.One of the example where Local Government taking an initiative is The Government of Scotland [11], where they concluded that street design should consider six qualities of successful places; distinctive, safe and pleasant, easy to move around, welcoming, adaptable and resource efficient. A significant amount of social activities within a community takes place in the external environment [11], and street design should encourage this by creating inclusive social spaces where for all group of society, and other appropriate activities can take place safely. In order for this to occur, it is essential that vehicular traffic does not dominate the street.

Maintenance of the street and surrounding buildings are also important where it affect safety perception. Unkempt area is one of the factor that trigger culprit to commit their crime as implied in 'broken window' theory. It also affect women's safety perception.

Perceptions of safety are influenced by many factors such as social, economic, cultural, environment and demographic [12] and women were constantly reported as registering more fear of crime than man. Rapoport [13] highlighted that perception is the key process to connect people within the surrounding environment related to man and environment.

Gender has been found consistently and strongly as an important factor associated with fear of crime. Women in general feel fearful compared to man [14] and within the same street environment. Women uses the street for many purposes from household-serving, traveling for work and leisure and at different time [15]. Therefore the feeling of fear is presence especially for women who needs to commute at night where crime might occur during this time.

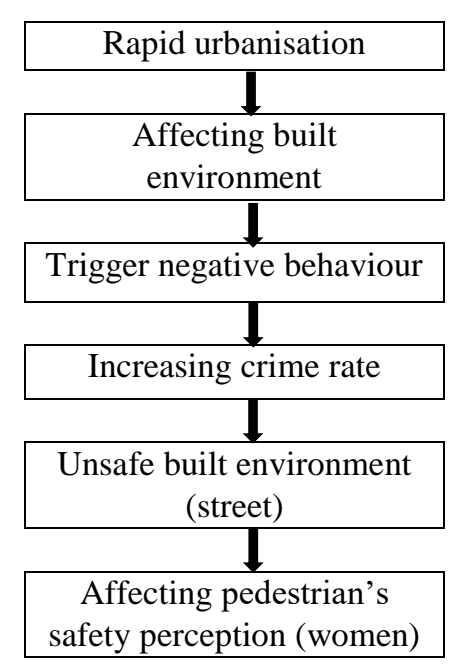

Fig. 1 Rapid urbanization impact on environment, social and behaviour

\section{ISSUES IN STREET DESIGN}

UN Habitat [10] addressed the issue of inefficiency or lack of urban planning and clearly suggest the high priority on early attention to planning when land is still inexpensive, in order to avoid future gridlocks and congestion. Current needs in urban development led to a different typology of street design and building blocks. Fine grain of building blocks has been replaced by coarse grain with large buildings and grid-design streets are replaced with wider and longer street. This changes in urban pattern creates an environment where people are more depending on vehicles and more priority is given to vehicles [16]. Advancement in technology and engineering gives way to traffic engineers and resulting a traffic and motorised oriented street [17].

With the changes in demand of building more high rise and also development in economic sector, contemporary buildings are more designed to meet a single purpose and this led to less pedestrian oriented environment with no fivefoot walkway, disconnected sidewalk and less ground floor spaces for pedestrian. The trend in globalization with high rise building has also created an individualized or isolated building and no connection of linkages which is important in walkability and safety. Pedestrian should be able to walk from one point to another without any interruption especially for women who are more vulnerable. More walkable environment and street should be provided with safety in mind. Comfortable and safe walking distance should be reconsider especially with the current trend of urban development.

Various research shows that there is also lack of gender consideration at planning stage [14] that lead to the current issue of safety. Current needs of vulnerable group especially women need to be address as what many Local Government are introducing and implementing [17].In order for women to feel safe, the environment itself should be design to avoid any negative impact of que to criminal. It has been addressed that many crime happens on the street.

\section{METHODOLOGY}

This study employed a mixed method approach with questionnaire survey, semi structured interview and structured observation. Due to the nature of this research problem, a mixed method is essential in order to investigate and obtain information needed [18]. Case study approach is adopted in order to gain in depth information of the problem [19]. Jalan Tunku Abdul Rahman in Kuala Lumpur is selected due to its characteristic which reflect traditional street with modern and shop houses. Study were conducted through sequence with questionnaire survey, followed by structured interview and structured observation. The scope of this study is focusing on women as user therefore 120 respondents were randomly selected among pedestrian in Jalan Tunku Abdul Rahman for questionnaire survey. Semi structured interview followed with six informants which were selected among women who use the street. Structured observation was conducted from weekdays until weekend where the nature of activities and demographic is not similar. The environment and social activities were studied at a set of time of the day and night to fully investigate the problem. 
Table. 1 Timeframe for structured observation

\begin{tabular}{|c|c|}
\hline Time & Justification \\
\hline $\begin{array}{l}\text { Weekdays } \\
(8.30-9.30 \mathrm{am}) \\
(12.30 \text { noon- } 2.30 \mathrm{pm}) \\
(5.00 \mathrm{pm}-7.00 \mathrm{pm}) \\
(8.30 \mathrm{pm}-9.30 \mathrm{pm}) \\
\end{array}$ & $\begin{array}{l}\text { Behaviour pattern during } \\
\text { working days } \\
\text { Demographic pattern }\end{array}$ \\
\hline $\begin{array}{l}\text { Weekend } \\
(8.30 \mathrm{am}-9.30 \mathrm{am}) \\
(12.30 \mathrm{noon}-2.30 \mathrm{pm}) \\
(5.00 \mathrm{pm}-7.00 \mathrm{pm}) \\
(8.30 \mathrm{pm}-9.30 \mathrm{pm})\end{array}$ & $\begin{array}{l}\text { Different pattern of street } \\
\text { activities } \\
\text { Demographic pattern }\end{array}$ \\
\hline
\end{tabular}

Data from all these techniques are triangulate in order to compare the findings and to complement each other and to further understand the phenomenon of being studied.

\section{FINDINGS}

From the study that has been carried out, it is evidence that physical and social elements contributes to safety perception among women in the street. Findings from questionnaire survey indicates that physical and social elements are important and affecting their safety perception. One of the main characteristic of the case study area is the mixture of building use where $87 \%$ respondents agreed that they feel safe when there are many types of building along the street. This finding is validated through observation where there is mixture of building use along the street that lead to variety of activities and occupation of the building until at least $8.00 \mathrm{pm}$ daily.

Table. 2 Mixture of building use

\begin{tabular}{|rl|r|r|r|r|}
\hline & $\begin{array}{c}\text { Frequenc } \\
\text { y }\end{array}$ & Percent & $\begin{array}{c}\text { Valid } \\
\text { Percent }\end{array}$ & $\begin{array}{r}\text { Cumulati } \\
\text { ve Percent }\end{array}$ \\
\hline Valid & $\begin{array}{l}\text { Strongly } \\
\text { agree }\end{array}$ & 22 & 18.3 & 18.3 & 18.3 \\
Agree & 87 & 72.5 & 72.5 & 90.8 \\
Disagree & 3 & 2.5 & 2.5 & 93.3 \\
Don't & 8 & 6.7 & 6.7 & 100.0 \\
know & & & & \\
Total & 120 & 100.0 & 100.0 & \\
\hline
\end{tabular}

From the above table, it indicates the significant contribution of planning, economic and relationship towards social aspect where various pattern of activities happens along the street and it definitely attract more user which then make the street feel safe by women.

Table 3 indicates that the provision of CCTV is important where the main street is well lit but the side lane connecting to the street still need to be improve. Results of questionnaire surveys shows that $44 \%$ agree that the provision of CCTV makes them feel safe while $31 \%$ strongly agree with this. Findings from interview validate the need of CCTV in the area. Therefore, it correlates with previous research that CCTV is part of contributing factors.
Table. 3 Provision of CCTV (source: fieldwork, 2018)

\begin{tabular}{|c|c|c|c|c|}
\hline & Frequency & Percent & $\begin{array}{c}\text { Valid } \\
\text { Percent }\end{array}$ & $\begin{array}{c}\text { Cumulative } \\
\text { Percent }\end{array}$ \\
\hline $\begin{array}{l}\text { Valid Strongly } \\
\text { agree } \\
\text { Agree }\end{array}$ & 31 & 25.8 & 25.8 & 25.8 \\
Disagree & 15 & 12.5 & 12.5 & 75.0 \\
$\begin{array}{l}\text { Don't } \\
\text { know } \\
\text { Total }\end{array}$ & 30 & 25.0 & 25.0 & 100.0 \\
\hline
\end{tabular}

Frequency of visit affect familiarity of the street and its surrounding where certain character and images stored in our mind and gives a certain que. Respondents was asked about their frequency visiting the area and whether they are willing to change their route whenever they feel unsafe (Table 4). Behavioural modification is predicted and addressed in various research where it is stimulated or affected by the environment. Base on questionnaire survey, it is found that there is a relationship between frequency and the way women use the street. In this study it shows that women will change the route whenever the find that the area is not safe.

Table. 4 Frequency of visit and change of route

\begin{tabular}{|ll|r|r|}
\hline & & frequency & \multicolumn{2}{c|}{$\begin{array}{c}\text { changed } \\
\text { route }\end{array}$} \\
\hline frequency & $\begin{array}{l}\text { Pearson } \\
\text { Correlation } \\
\text { Sig. (2- } \\
\text { tailed) } \\
\mathrm{N}\end{array}$ & 1 & .042 \\
\hline $\begin{array}{l}\text { Pearson } \\
\text { Coute }\end{array}$ & $\begin{array}{l}\text { Correlation } \\
\text { Sig. (2- } \\
\text { tailed) } \\
\mathrm{N}\end{array}$ & .042 & .649 \\
& & 120 & 120 \\
\hline
\end{tabular}

The above table shows the relationship between the two variables. Base on the interview, informants feels that they will change the route especially when they are familiar with the area. 
Table. 5 Elements that affect safety perception (source: fieldwork, 2018)

\begin{tabular}{|c|c|c|}
\hline Technique & Physical & Social \\
\hline $\begin{array}{l}\text { Questionnaire } \\
\qquad(\mathbf{n}=\mathbf{1 2 0})\end{array}$ & $\begin{array}{l}\text { Visibility } \\
\text { Mixture of land } \\
\text { use } \\
\text { Street pattern } \\
\text { Lighting } \\
\text { Accessibility } \\
\text { Maintenance } \\
\text { Provision } \\
\text { CCTV } \\
\text { Orientation of the } \\
\text { buildings } \\
\text { Incivilities } \\
\end{array}$ & $\begin{array}{l}\text { Overcrowding } \\
\text { Presence of } \\
\text { foreigners } \\
\text { Deserted area } \\
\text { News and } \\
\text { stories } \\
\text { Presence of } \\
\text { police } \\
\text { Past experience } \\
\text { Familiarity }\end{array}$ \\
\hline Interview & $\begin{array}{l}\text { Sidewalk } \\
\text { Crowded Side lane } \\
\text { Conflict between } \\
\text { pedestrian and } \\
\text { vehicles } \\
\text { Vehicle's speed } \\
\text { Provision } \\
\text { CCTV }\end{array}$ & $\begin{array}{l}\text { Overcrowding } \\
\text { Presence of } \\
\text { foreigners } \\
\text { Presence of } \\
\text { police } \\
\text { Familiarity } \\
\text { Time }\end{array}$ \\
\hline Observation & $\begin{array}{l}\text { Disrupted linkages } \\
\text { Quite side and } \\
\text { back lane } \\
\text { Lighting }\end{array}$ & $\begin{array}{l}\text { Overcrowding } \\
\text { Incivilities }\end{array}$ \\
\hline
\end{tabular}

Table 5 shows the elements that affect safety perception from all the techniques that has been tested and the themes that emerged from the interview that has been conducted.

The findings suggest that the width of the sidewalk is wide enough for the pedestrian but the linkages is disrupted where there are too many food stalls in front of the shopping mall. In terms of design, the sidewalk has been upgraded with landscaping and street furniture which invites pedestrian to fully utilized it for social activities.

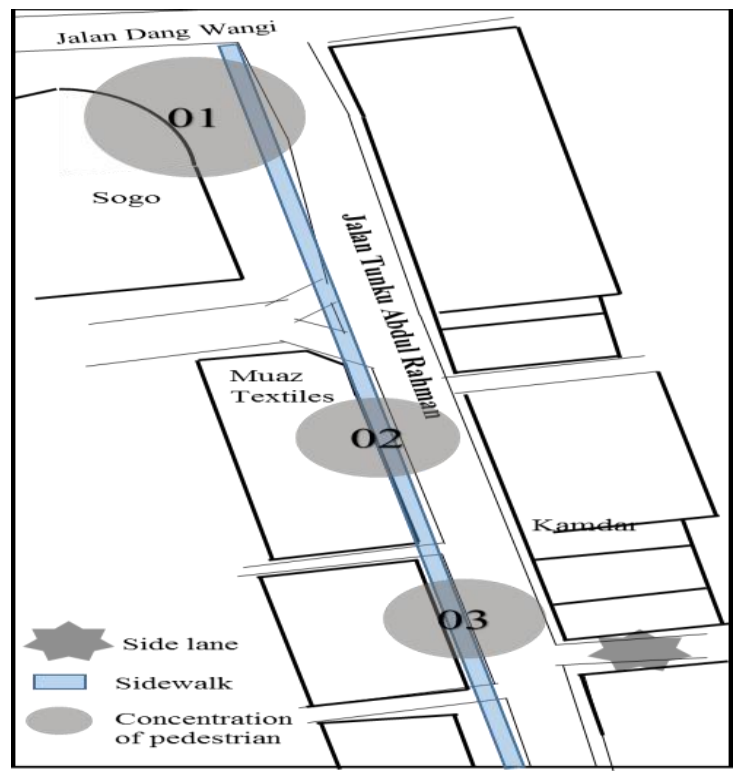

Fig. 2 Case study area of Jalan Tunku Abdul Rahman, Kuala Lumpur (source: field work, 2018)

Sidewalk in front of the shop houses are wider therefore it provides better ambience for pedestrian, as indicated in
Figure 2. Main entrance of Sogo is attracting more pedestrian due to its size and further down, the concentration of pedestrian is still visible. Shop houses on the right side of the street are still maintaining its five-foot walkway with smaller sidewalk. Therefore, the walking experience is different and according to interview data, some women feel unsafe walking on a five-foot walkway compared to sidewalk due to the many foreigners who work in these shop houses along the street.

Side lane where activities are provided such as stalls creates more vibrant public space compared to side lane which only dedicated for motorcycle parking. But due to the overcrowding, some pedestrian avoids this side lane and data from interview confirmed that women do feel unsafe when the street is too crowded. This is correlate with the theory that overcrowding affect safety perception. Data from interview shows that informant felt it is unsafe along the sidewalk of Jalan Tunku Abdul Rahman due the presence of many foreigners and they avoid walking in the five-foot walkway.

"..I feel insecure because there are so many foreigners along this sidewalk, especially for me with my kids. I feel like there is no freedom and I don't feel like we are living in Malaysia"

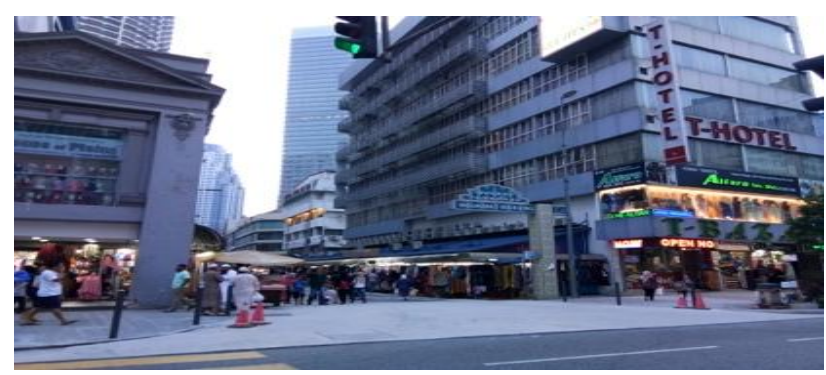

Fig. 3 Crowded side lane with many shops and pedestrian (source: field work, 2018)

Human presence is important not only on the main street but along the side lane where there are connected to parking area and leading to public transport. From observation it is found that there is side lane which is quite due to the design. It is dedicated for motorcycle parking and there is no visual surveillance from inside of the building as shown in Figure 4.

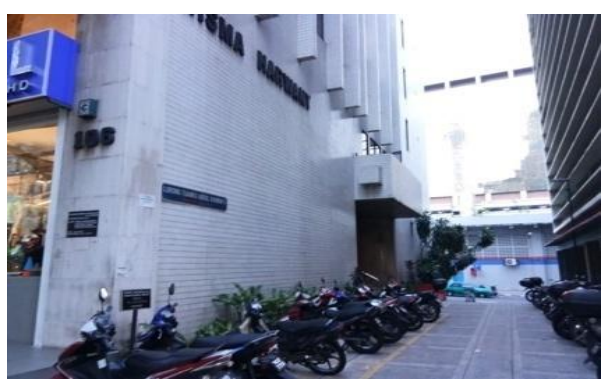

Fig. 4 Side lane (source: field work, 2018)

Linkages are visually clear but at certain time it is disrupted by activities especially in front of Sogo where access for pedestrian became narrower. 


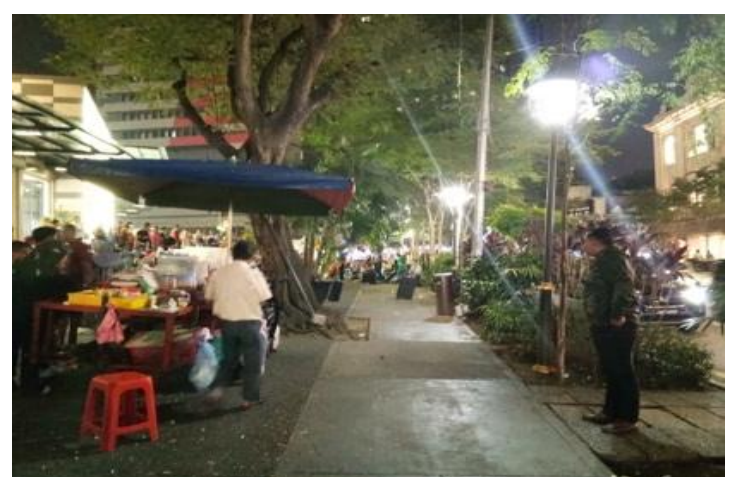

Fig. 5 Disrupted linkages in front of Sogo (source: field work, 2018)

In terms of demographic usage of the street, it is mostly dominated by women from morning until night time where most of them are workers and students. Data from observation concurred that women needs for safety is crucial in order for them to feel safe while using the street.

\section{CONCLUSION}

From the above study, it was found that both physical and social factors are important in designing a safe street for women. Physical factors are important in creating and affecting a safe environment due to its permanent nature compared to social factors. Findings from both data shows confirmed that physical design of the street and the buildings affect safety perception among women. The street has been up graded with street furniture and landscaping by the Local Authority but somehow the perception of feeling unsafe is still felt by women. Social factors which is crowding especially among foreigners are making women feel unsafe, however at certain area, less presence of pedestrian does also affect their feeling. The issues of foreign men dominating the street as workers at the shop along the streets need to be address by policy makers in relevant field because their presence is changing the demographic of the area and creating an unpleasant experience for the women due to their behavior.

Therefore, it is important for architects, town planners, policy makers and stakeholders to investigate, consider and address the issues and needs of safety for general public and for women especially.

\section{ACKNOWLEDGMENT}

The author would like to express sincere gratitude to the Ministry of Education Malaysia, Universiti Teknologi Malaysia and Research and Management Centre (RMC) of UTM for providing the financial support for this research. This research is financed by the Grant for Research University (GUP) Tier 2 of UTM for research funding under Cost Centre No. R.K 130000.7740.4J298.

\section{REFERENCE}

1. E. Duflo, Women Empowerment and Economic Development, American Economic Association, Vol.50, No.4, 2012, pp. 1051-1079.

2. UN, Sustainable Development Goals Report, New York, 2018

3. M.Felson \& R.V.Clarke, Opportunity Makes The Thief: Practical Theory for Crime Prevention, Police Research Paper, 1998.

4. The Star,Move to Curb Street Crime, https://www.thestar.com.my, 2015
5. UN Women, Safe Cities Global Initiatives, https://www.unwomen.org, 2011

6. UN Women, Safe Cities and Safe Public Spaces, Global Results Report, 2017.

7. UN, Sustainable Development Goals Report, New York, 2018.

8. V.Mehta, Lively Street: Determining Environmental Characteristics to Support Social Behaviour, Sage Publication, Vol.27, Issue 2, 2007.

9. A.B.Jacobs, Great Street, MIT Press, USA, 1993.

10. UN Habitat, The Relevance of Street Patterns and Public Space in Urban Areas, UN Habitat Working Paper, United Nations Human Settlements Programme, 2013.

11. The Government of Scotland, Designing Streets: A Policy Statement for Scotland, 2010, http://www.beta.gov.scot

12. C.Boulange, The Effect of Urban Crime and Perceived Safety on Urban Levels of Physical Activity: A Review, World Health Organisation, Kobe Centre for Health Development, retrieved from https://www.who.int, 2011.

13. A.Rapoport, Human Aspect of Urban Form, Towards a ManEnvironment Approach to Urban Form and Design, Pergamon Press, New York, 1977.

14. P.N. Grabosky,Fear of Crime and Fear Reduction Strategies, Australia Institute of Criminology, 1995.

15. UN Women, Safe Public Transit for Women and Girls, 2012 www.htt://endvawnow.org

16. S.Marshall, Street \& Patterns, Spon Press, New York, 2005.

17. P.Jones, S.Marshall \& N.Boujenko, Creating More People-Friendly Urban Street Through 'Link and Place' Street Planning and Design, IATSS Research, Volume 32, Issue 31, Pages 14-25, 2008

18. J.W. Creswell,Research Design: Qualitative, Quantitative and Mixed Methods Approaches, Second Edition, Sage Publications,Inc. USA, 2003.

19. R.K.Yin, Case Study Research: Design and Method ( $4^{\text {th }}$ Edition), Thousand Oaks, California, 2009. 